\title{
American Astronomical Society
}

Founded in 1899 for the advancement of astronomy and closely related branches of science

JAMES E. HESSER*

Dominion Astrophysical Observatory Vice President

\author{
OFFICERS \\ SIDNEY C. WOLFF* \\ AURA/NOAO \\ President \\ FRANK H. SHU* \\ University of California, Berkeley \\ President-Elect \\ DONALD B. CAMPBELL* \\ Cornell University \\ Vice President
}

FRANCE A. CORDOVA

Pennsylvania State University Vice President

\author{
ROGER A. BELL* \\ University of Maryland \\ Secretary \\ PETER B. BOYCE* \\ American Astronomical Society \\ 1630 Connecticut Avenue, NW, Suite 200 \\ Washington, DC 20009 (202-328-2010) \\ Executive Officer
}

Suzan Edwards

Richard G. Kron

Mark M. Phillips

\section{COUNCILORS}

Anita L. Cochran

Sara R. Heap

David J. Hollenbach

*Executive Committee

\section{ROBERT O'DELL* \\ Rice University \\ Treasurer}

MARY K. HEMENWAY

University of Texas at Austin Education Officer

\section{SUSTAINING CORPORATE MEMBERS}

\section{Corning, Incorporated \\ Corning, New York}

\author{
Eastman Kodak Company \\ Rochester, New York
}

Martin Marietta

Bethesda, Maryland

\author{
Bruce Balick \\ Judith Pipher \\ Lee Anne Willson
}

REGULAR CORPORATE MEMBERS

The Aerospace Corporation

Los Angeles, California

Associated Universities, Inc. National Radio Astronomy Observatory Charlottesville, Virginia

Association of Universities for Research in Astronomy, Inc. Washington, DC

AutoScope Corporation Mesa, Arizona

Ball Aerospace Systems Group Boulder, Colorado

American Institute of Physics Woodbury, New York

Astronomical Society of the Pacific San Francisco, California Astronomy Magazine

Kalmbach Publishing Company Waukesha, Wisconsin

Stanly E. Black, AIA, Architects Boston, Massachusetts

Cambridge University Press New York, New York

\author{
Boeing Defense and Space Group \\ Seattle, Washington \\ Computer Sciences Corporation \\ Lanham/Seabrook, Maryland \\ Eureka Scientific \\ Oakland, California \\ Grumman Corporation \\ Bethpage, New York \\ Hughes STX Corporation \\ Lanham, Maryland \\ L \& F Industries \\ Huntington Park, California
}

\section{PUBLISHER AFFILIATE MEMBERS}

\author{
L. Davis Press \\ Schenectady, New York \\ IOP Publishing, Ltd. \\ Bristól, England \\ Kluwer Academic Publishers \\ Dordrecht, The Netherlands \\ Oxford University Press \\ New York, New York \\ Pergamon Press, Ltd. \\ Oxford, England \\ Saunders College Publishing \\ Philadelphia, Pennsylvania
}

Hughes Danbury Optical Systems, Inc. Danbury, Connecticut

\author{
Lockheed Missiles and Space Company \\ Palo Alto, California \\ National Astronomy and Ionosphere Center \\ Arecibo Observatory \\ Arecibo, Puerto Rico \\ Science Applications International Corporation \\ Reston, Virginia \\ Southwest Research Institute \\ San Antonio, Texas \\ Universities Space Research Association \\ Washington, DC \\ University Corporation for Atmospheric Research \\ Boulder, Colorado
}

\footnotetext{
Sky Publishing Corporation Belmont, Massachusetts

Springer-Verlag New York, Inc. New York, New York

University of Chicago Press Chicago, Illinois

University Science Books Mill Valley, California

John Wiley \& Sons, Inc.

Wiley Interscience Division New York, New York
}

Publications of the American Astronomical Society are: The Astrophysical Journal (ApJ), The Astrophysical Journal Supplement Series (ApJS), The Astronomical Journal $(A J)$, and The Bulletin of the American Astronomical Society (BAAS). Annual membership dues in the Society are: Junior, $\$ 25.00$; Associate, $\$ 85.00$; Member, $\$ 85.00$. Applications should be addressed to Dr. Peter B. Boyce, American Astronomical Society, 1630 Connecticut Avenue, NW, Suite 200, Washington, DC 20009. Refer to inside front cover for information regarding subscriptions to $A p J$ and $A p J S$. Subscriptions for $A J$ and $B A A S$ are payable to: The American Astronomical Society, 1630 Connecticut Avenue, NW, Suite 200, Washington, DC 20009. 


\section{THE ASTROPHYSICAL JOURNAL SUPPLEMENT SERIES}

\section{TENTATIVE TABLE OF CONTENTS NOW SCHEDULED \\ FOR THE 1994 MARCH ISSUE}

THE PARKES-MIT-NRAO (PMN) SURVEYS. II. SOURCE CATALOG FOR THE SOUTHERN SURVEY $\left(-87^{\circ} .5<\delta<-37^{\circ}\right)$ Alan E. Wright, Mark R. Griffith, B. F. Burke, \& R. D. Ekers

SEARCH FOR IMPORTANT WEAK INTERACTION NUCLEI IN PRESUPERNOVA EVOLUTION

Maurice B. Aufderheide, Ikko Fushiki, Stanford E. Woosley, \& Dieter H. Hartmann

NEUTRAL HYDROGEN AND OPTICAL PROPERTIES OF THREE AMORPHOUS GALAXIES

Deidre A. Hunter, Hugo van Woerden, \& John S. Gallagher III

A $5 \mathrm{GHz}$ VLA SURVEY OF THE GALACTIC PLANE

Robert H. Becker, Richard L. White, David J. Helfand, \& S. Zoonematkermani

SOLAR ACTIVE REGION EXTREME ULTRAVIOLET SPECTRUM FROM SERTS

Roger J. Thomas \& Werner M. Neupert

OPEN CLUSTER CHEMICAL COMPOSITION. I. LATER TYPE STARS IN EIGHT CLUSTERS R. Earle Luck

THE LYMAN-ALPHA FOREST NEAR 34 QUASI-STELLAR OBJECTS WITH $z>2.6$ Jill Bechtold

CALCULATION OF ${ }^{12} \mathrm{C}^{16} \mathrm{O}$ AND ${ }^{13} \mathrm{C}^{16} \mathrm{O} X{ }^{1} \Sigma^{+}$ROVIBRATIONAL INTENSITIES FOR $v \leq 20$ AND $J \leq 150$ D. Goorvitch \& C. Chackerian, Jr.

COMPARISON OF THE PLASMA TAILS OF FOUR COMETS: P/HALLEY, OKAZAKI-LEVY-RUDENKO, AUSTIN, AND LEVY Tony L. Farmham \& Karen J. Meech

NOTE.-Titles and sequence subject to change during the publishing process.

THE ASTROPHYSICAL JOURNAL SUPPLEMENT SERIES is a monthly publication of 2 issues per volume, 6 volumes per year. Regarding subscription information, see the inside front cover of a current issue of the Supplement Series.

Paper edition back issues are available from 1984 (Vol.54). Microfiche back issues are available from 1982 (Vol. 49). Please inquire about prices and availability.

THE UNIVERSITY OF CHICAGO PRESS•5801 ELLIS AVENUE, CHICAGO, ILLINOIS 60637 